\section{Cystiske lesjoner i pancreas}

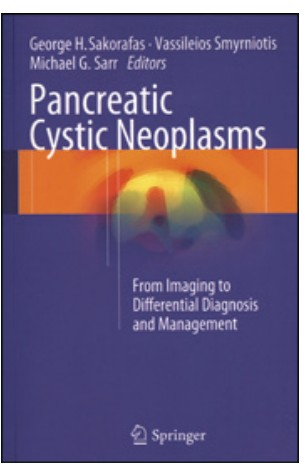

George H. Sakorafas, Vassileios Smyrniotis, Michael Sarr, red.

Pancreatic cystic neoplasms

From imaging to differential diagnosis and management. $74 \mathrm{~s}$, tab, ill. Heidelberg: Springer, 2015. Pris EUR 60 ISBN 978-88-470-5707-4

Moderne bildediagnostikk blir stadig mer utviklet, men også mer brukt for å avklare en rekke kliniske problemstillinger. Cystiske forandringer, gjerne i lever, nyrer eller milt, påvises hos inntil $30 \%$ av pasienter som henvises til bildediagnostikk av ulike årsaker. Mange av disse pasientene får også tilfeldig påvist cystiske lesjoner i pancreas, selv om bildeundersøkelsen var rekvirert på annen indikasjon enn spørsmål om pancreassykdom. Det bidrar til å skape et nytt «problem» for rekvirenten, og kanskje også en ny bekymring hos pasienten. For kliniker og radiolog som skal avklare lesjonen videre, ofte med supplerende undersøkelser, byr dette ikke sjelden på diagnostiske utfordringer. Målet er en trygg og effektiv diagnostikk og klinisk håndtering, uten å utsette pasientene for over- eller underdiagnostikk - eller behandling.

Redaktørene har gjennom egne bidrag, men også gjennom andre forfattere som omtaler henholdsvis patologi og bildediagnostikk av disse cystiske pancreaslesjonene, klart å lage en «state of the art»fremstilling av høy kvalitet. Insidens, epidemiologi, morfologisk diagnostikk, bildediagnostikk, klinisk diagnostikk, behandling og oppfølging blir behandlet i sju ulike kapitler. Enkelte gode tabeller bidrar til å holde oversikten. Teksten er konsis og lettlest, og layouten og illustrasjonene er gjennomgående gode. På tross av litt overlapping mellom enkelte kapitler er redigeringen god. Referansene er sentrale og oppdaterte, inkludert flere nyere artikler fra spesielt Sarkorafas og Sarr. Det er hyggelig å registrere at de kliniske anbefalingene som gis, i store trekk er helt i overenstemmelse med de norske retningslinjene (1).

Denne kortfattede boken vil være relevant for mange som på ulike vis er involvert i pasientgruppen. I særlig grad vil gastrokirurger, radiologer, gastroenterologer og patologer ha nytte av denne multidisiplinære fremstillingen, som kan hjelpe oss til å bli bedre sammen - trolig til nytte for våre pasienter.

\section{Jon Arne Søreide}

Overlege, Avdeling for gastroenterologisk kirurgi

Stavanger universitetssjukehus

\section{Litteratur}

1. Nasjonalt handlingsprogram med retningslinjer for diagnostikk, behandling og oppfølging av pasienter med pancreaskreft. Oslo: Helsedirektoratet, 2014, revidert januar 2015. https://helsedirektoratet.no/Lists/Publikasjoner/Attachments/ 880/IS\%202274\%20Handlingsprogram\%20pancreaskreft.pdf (18.3.2015).

\section{Godt bidrag til økt sikkerhet i medikamentbruk}

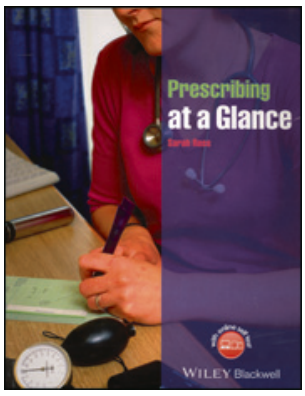

Sarah Ross

Prescribing at a glance

86 s, tab, ill. Chichester: Wiley-Blackwell,

2014. Pris GBP 25

ISBN 978-1-118-25731-9

Målgruppen for hele serien er i første rekke medisinstudenter og nyutdannede leger, men denne boken kan også med fordel brukes som et oppslagsverk for erfarne leger og sykepleiere. Forfatterens intensjon er å bidra til sikker forskrivning med søkelys på sykehusmedisin, men prinsippene gjelder også i primærhelsetjenesten.

Boken er én av 55 bøker eller hefter utgitt i serien At a glance. Den er oppdelt i 39 oversiktlige kapitler, der hvert enkelt kapittel kan ha nytte hver for seg. Den er i A4-format med tynne permer og godt papir.

Førstesiden i hvert kapittel har gjerne en tabell eller illustrasjon som rettferdiggjør tittelen At a glance. Det meste passer godt for norske forhold, men et par kapitler gjelder hovedsakelig for Storbritannia.

Forfatteren gir konsise anbefalinger som i de aller fleste tilfeller samsvarer med norsk praksis. Hun skiller mellom hva som forskrives av allmennleger, og hva som forventes å tilhøre spesialisthelsetjenestens ansvarsområde.

Kapittel 16, Prescribing in children, henviser til British National Formulary for Children (BNFC). Vi har ikke noe tilsvarende i Norge. Det er en database tilgjengelig for norske leger gjennom Helsebiblioteket.

Boken har fem deler. Del én omhandler basale prinsipper, del to valg av medikament, del tre forskrivning til spesielle grupper, og del fire handler om logistikk. Del fem inneholder 15 kapitler om spesifikke medikamentgrupper. Denne inndelingen gjør at leseren raskt kan finne frem til aktuell problemstilling hvis man bruker boken som et oppslagsverk. Legemiddelbivirkninger og kontraindikasjoner er hyppig omtalt. Disse påminnelsene kan forhåpentligvis spare oss for en sykehusinnleggelse eller to.

For mer inngående studier, eller for å teste egne kunnskaper, finnes det en quiz og flervalgsoppgaver (multiple choice questions) på nettet. Se www.ataglanceseries.com/prescribing. En elektronisk versjon av boken kan kjøpes på Wiley E-Text hos forlaget.

Dagfinn Krogsæter

Fastlege, Legegruppa SMS i Florø 